\title{
The Iranian foreign policy in turbulent times: The Arab uprisings, the nuclear deal and the GCC crisis
}

\author{
La politica exterior irani en tiempos turbulentos: \\ las revueltas árabes, el acuerdo nuclear y la crisis del CCG
}

\author{
LUCIANO ZACCARA \\ Gulf Studies Center, Qatar University
}

\section{Cómo citar/Citation}

Zaccara, L. (2021). The Iranian foreign policy in turbulent times: The Arab uprisings, the nuclear deal and the GCC crisis. Revista Española de Ciencia Política, 56, 49-70. Doi: https://doi.org/10.21308/recp.56.02

\begin{abstract}
Using the Foreign Policy Analysis framework and the concept of Authoritative Decision Units, this article analyzes three cases that required an Iranian response: the Arab Uprisings, the nuclear negotiations, and the 2017 GCC Crisis. The article argues that it was not a single actor taking the foreign policy decisions in those cases, but a combination of individual and collective actors that formed the decision units that designed and implemented Iranian foreign policy. It also contends that those decisions were in line with the overall Iranian foreign policy objective - which is to convert Iran into a regional power- and, to that aim, variations of non-alignment strategies were implemented.
\end{abstract}

Keywords: Iranian foreign policy, foreign policy analysis, JCPOA, Arab uprisings, GCC crisis.

\section{Resumen}

Utilizando el marco teórico del análisis de política exterior y el concepto de unidades de decisión autoritativas, este artículo analiza tres casos que requirieron la respuesta iraní: la Primavera Árabe, las negociaciones nucleares y la crisis del CCG de 2017. El artículo argumenta que no ha sido un actor individual, sino la combinación de actores individuales y colectivos los que tomaron las decisiones, conformando las unidades de decisión que diseńaron e implementaron la política exterior. También se sostiene que las decisiones tomadas se alineaban con el objetivo principal de la política exterior iraní, que es la de convertir a Irán en una potencia regional, para lo cual se implementaron diversas variaciones en las estrategias de no alineamiento.

Palabras clave: política exterior iraní, análisis de política exterior, acuerdo nuclear iraní, Primavera Árabe, crisis del CCG. 


\section{INTRODUCTION}

The literature on Iranian foreign policy often claims that a single and omnipresent actor, the Leader of the Islamic Republic, takes decisions arbitrarily ${ }^{1}$. However, Foreign Policy Analysis, a sub-discipline of International Relations provides the necessary tools to describe and analyze how decisions are taken within the "black box" of foreign policymaking. In the Iranian case, individuals, agencies, and departments form the "foreign policy complex" (Entessar and Afrasiabi, 2017: 96) that intervenes in the design and implementation of foreign policy, and those individuals and organizations do not always share the same values, political orientations and objectives. This article aims to demystify the individuality of the Iranian foreign policymaking by claiming that the "authoritative decision units" (ADU), as defined by Margaret Hermann (2001: 88), are formed within the formal and informal political structure of the state, to address one particular foreign policy problem. In order to do that, this piece focuses on three particular situations that needed a response by Iranian foreign policymakers. Those who were able to mobilize the needed resources and influences shaped the ADU that responded to these particular situations, whether policymakers agreed or even disagreed with other actors within the foreign policy complex.

The three cases examined in this article are the Iranian response to the Arab Uprisings of 2011, the nuclear negotiations that ended with the signing of the JCPOA in 2015, and the Iranian position on the 2017 Gulf Cooperation Council (GCC) that drove to a blockade against Qatar until December 2020. In order to properly address the three cases, it is necessary to understand how the Iranian foreign policy is designed and implemented, and who are the internal actors that shape the ADU. It is also necessary to know the Iranian foreign policy strategies that were implemented to achieve those objectives. This article argues that Iran has a long-term foreign policy objective, which is to convert Iran into a regional power. This objective existed since the times of Shah Reza Pahlavi (1941-1979), and after the establishment of the Islamic

1. According to article 109 of the Iranian Constitution, the Leader of the Islamic Republic is the head of the state, and this position should be occupied by a person who has the following qualifications: "1. scholarly qualification for issuing religious ruling (fatwa) concerning various discussions in jurisprudence; 2. required justice and piety in leading the Islamic community; 3. sound political and social perspective, prudence, courage, sufficient administrative capability, and power for leadership". Article 107 established Ayatollah Ruhollah Khomeini as the first person to occupy that position. After his death in June 1989, Ayatollah Ali Khamenei was chosen as the second Leader by the Assembly of Experts.

2. Term borrowed by International Relations from the discipline of Computer Science to refer to the foreign policy decision mechanisms that exist in every state. A black box is a system that can be viewed in terms of its inputs and outputs without any knowledge of its internal workings. This way, International Relations adapted its analysis to an opaque system in which only inputs and outputs were visible, but not the way in which the mechanism works. 
Republic in 1979. The foreign policy strategies, both pre- and post-revolution, were in line with this objective although with different tools and ideological justification, and the cases discussed in this article demonstrate how the responses given aimed at complying with that long-term foreign policy objective of making Iran a regional power (Zaccara, 2016: 187).

This article does not aim at establishing a complete chronology of the different types of ADUs that can be identified along Iran's republican history. Instead, it aims at using the concept of ADU to demystify the often-erroneous assumption that Iran is run by a single omnipresent figure or a homogenous, reduced and unchangeable elite at the top of the political regime. The ADUs serve to explain how decisions were taken and how policies were defined in the three cases this article deals with. Thus, the article is divided into seven sections, apart from introduction and conclusions. The first one describes the function of the authoritative decision units. The second one deals with the Iranian foreign policy making mechanisms. The third and four ones discusses Iranian regional power status and foreign policy objectives and strategies. The fifth, six and seven sections examine three case studies: the Arab Uprisings; the nuclear negotiations and the GCC crisis.

\section{FOREIGN POLICY ANALYSIS AND AUTHORATIVE DECISION UNITS}

This article uses the theoretical-methodological framework of Foreign Policy Analysis (FPA), an International Relations sub-discipline that emerged in the 1950s, in the Cold War context between the United States and the Soviet Union, with the predominance of political realism as the main theoretical trend at that time. Realism was more interested in looking at the outputs of foreign policy rather than how decisions were taken, because states were considered "single rational actors". The black box in which decisions were made was not, therefore, a preoccupation for realist theorists (Nonneman, 2005: 7). Because of that, realists and neo-realists tended to disregard internal factors, "neglect of ideology and belief systems, a minimization of factors internal to states and societies, inadequate attention to economics, and, of special importance for the misrepresentation of the Middle East, a view of inter-state relations as marked by timeless, recurrent, patterns" (Halliday, 2005: 25). As a result, realism has been losing ground in FPA in the decades following the Cold War. However, it still influences the discipline in one of its underlying theoretical assumptions: that states are the main actors in foreign policy, and that political elites tend to maximize the autonomy and security of the state (Hinnebusch, 2002: 1).

Further developments in the theoretical approaches of FPA focused on the decision-making processes, the national actors involved in them, and the contexts influencing those processes (Hudson, 2008: 13-15). Thus, the performance of state bureaucracies in the decision making processes (Halperin-Clapp, 2006: 4-6) as well as the "national role" perceptions of those elites involved in the decision making (Holsti, 1970: 245-246) became the most relevant features of FPA from the 1970s onwards. 
In addition, the constructivist current within the FPA provided more weight to "social factors" in determining the national interest and world politics (Checkel, 2008: 75).

A halfway approach to the abovementioned ones was provided by the definition of the "authoritative decision unit" (ADU) in foreign policy (Herman, 2001). According to this approach, authority is exercised by different national entities such as monarchs, presidents, prime ministers, party leaders, cabinets, and bureaucracies. Depending on the nature of the foreign policy problem and the structure of government, individuals or groups of actors organize in a way so they can mobilize the needed resources in order to overcome the problem and to decide upon which policies to implement. Those individuals and groups of actors form the ADU that shapes foreign policy decision-making (ibid:: 88). Herman identifies three different types of ADU:

- Predominant Leader: A single individual who has the ability to stifle all opposition and dissent as well as the power to make a decision alone, if necessary.

- Single Group: A set of individuals, all of whom are members of a single body, who collectively select a course of action in consultation with each other.

- Coalition of Autonomous Actors: The necessary actors are separate individuals, groups, or representatives of institutions which, if some or all concur, can act for the government, but no one of which by itself has the ability to decide and force compliance on the others; moreover, no overarching authoritative body exists in which all these actors are members (ibid: 57).

The existence of one ADU type at a specific moment does not mean it will last in the same format, rather it is related to the particular circumstances in which it was created to address one precise foreign policy problem. How these units are shaped depends on the formal and informal governmental structure, the type of leadership, and the existence of individual actors with the capacity to commit the needed resources. Different situations, circumstances, and historical periods favor other types of ADU. For instance, and still according to Herman, Iran passed through the "Coalition of Autonomous Actors" (CAA) ADU type during the times of President Mohammad Khatami (1997-2005) and during the US Embassy hostage crisis of November 1979. In both cases, neither did any of the individual actors or groups have absolute control over the foreign policy decision making, nor did they share the same line of action, driving to a series of contradictory foreign policy outputs that generated internal political crises (ibid: : 58-61).

\section{THE IRANIAN FOREIGN POLYCY MAKING}

The scholarly literature on Iranian foreign policy-making often starts by asserting that the Leader of the Islamic Republic has the last word in every decision; therefore, he is considered the only decision-maker in Iran. However, a more in-depth analysis of the different periods the Islamic Republic passed through as well as the foreign 
policy situations and problems addressed by the authorities at those times provides enough evidence to assert that the Leader is neither an absolute or unique autocrat nor that the foreign policy decisions were taken only by him throughout the 40 years of republican history. Instead, a combination of the three ADU types has occurred from 1979 until today, with specific periods when a "predominant leader" (PL) was able to impose his principles and determine actions, as well as other periods when the cohabitation of different political tendencies in the government was the leading feature (CAA). Besides, there were several periods when all members of the same political group shared the same ideas and positions within the foreign policy-making complex (Single Group, SG).

The abovementioned argument can be sustained by the description of the foreign policy complex within the Iranian political structure in which decisions are made. This complex is constituted by formal and informal institutions and groups that influence the policy-making process. The ADUs were shaped in a different manner depending on the strength of the political-religious figure that occupied a particular position in each period combined with internal and external determining factors. For instance, immediately after the Islamic Revolution of 1979, the power struggle between the different revolutionary groups favored the CAA type, while once the revolution consolidated after 1983, the SG type was the most prevalent one. Ruhollah Khomeini, the founder of the Islamic Republic, exercised the PL type on many occasions, for instance regarding the decisions taken around the continuation of the IranIraq war and the acceptance of the 1988 cease-fire, as well as the decision around the 1989 fatwa against Salman Rushdie.

Hence, the Iranian foreign policy complex is composed of many governmental organizations that, according to the constitution, are responsible for the state's external policies. Apart from the Leader of the Islamic Republic — who establishes the general ideological and political guidelines-, the head of the Executive Power - the elected president - and the Ministry of Foreign Affairs are the figures in charge of designing and implementing foreign policy. In addition, according to the constitution and practice over forty years, collective institutions such as the Supreme National Security Council (SNSC) and the Expediency Council (EC) had and have a determining role in external affairs. Composed by ex-officio and appointed members variably, the SNSC has most of the time been in charge of the nuclear dossier; its chairman has therefore been the most visible face during international negotiations. Hassan Rouhani, the current president of Iran, became a worldwide known figure while occupying that position. The same can be said about the EC, chaired by Hashemi Rafsanjani (1997-2017), when making critical decisions in foreign policy during the rapprochement process with the EU or the Taliban crisis in 1998. The last formal group that, according to the constitution, has a say in foreign policy matters is the Foreign Policy and Security Committee of the Islamic Consultative Assembly (Majlis, or parliament).

Other governmental institutions influence the implementation of Iranian foreign policy, and sometimes its design, depending on the period or situation. These include, 
first, the ministries of Defense; Intelligence; Culture and Islamic Guidance; the Chief Commander of the Islamic Revolutionary Guard Corps (Sepah-e Pasdaran, IRGC); the Chief Commander of the regular Army (Artesh); and the Foreign Policy Council - formed by the former foreign ministers. Moreover, other groups, forces, and institutions can influence the foreign policy decisions, such as the Ministry of the Interior, several think tanks and news media groups, and semi-formal factions and political as well as religious associations.

All the above-mentioned individuals and organizations participate in one way or another in the foreign policy complex, in form of one of the diverse ADUs previously identified, and in order to address the foreign policy problems and actions needed throughout the forty years of existence of the Islamic Republic. It is therefore possible to track the existence of those ADUs in the three cases analyzed in this article. The cases comprise a period ranging from 2011 until 2017. In that period, there was only one leader of the Islamic Republic, Ali Khamenei, but two different presidents —Mahmoud Ahmadinejad until August 2013 and Hassan Rouhani afterwards_-, as well as two different foreign ministers —Ali Akbar Salehi and Mohammad Javad Zarif. Moreover, there were also two different heads of the Expediency Council - Hashemi Rafsanjani until his death in January 2017, and Mahmoud Hashemi Shahroudi since then - and two National Security Council chairpersons - Saeed Jalili, until September 2013, and Ali Shamkhani later on. The combination of all these personalities provide different inputs to the "foreign policy complex" in charge of the decision making process that can explain the decisions taken in the three cases.

\section{IRAN AS A "REGIONAL POWER”}

Iran has long competed for power and influence with other countries in the Middle East, before and after the 1979 Islamic Revolution. It is a competition characterized by territorial conflict, cultural differences, and, since the creation of the Islamic Republic, ideological contention. A recurrent element in much of the literature on Iranian foreign policy analysis is the assumption that the permanent objective of Iran is to become a "regional power" in the region, not just in the Persian Gulf, but also the greater Middle East and Central Asia. Works on Iran's foreign policy have generally agreed with the characterization of its significant role in the broad Middle East region. Ruhollah Ramazani — for sixty years the most prominent analyst of Iranian foreign policy - ascribed Iran the characteristic of a "medium power" able "to create and maintain a favorable regional environment while aspiring to global political stature"; a feature that the late Shah Mohammad Reza Pahlavi (1941-1979) had achieved, and which was continued by the authorities of the Islamic Republic (Ramazani, 2013: 86-87). Following a similar reasoning, Ehteshami and Hinnebusch also attributed Iran the characteristic of a "middle power" due to the geographical range and scope of its foreign policy and its capabilities. Within this range, a regional middle power can exert a credible deterrent capability and resist a coalition of other 
regional actors, mainly when an exogenous great power penetrates the regional system and threatens its sovereignty, which applies in the Iranian case (Ehteshami and Hinnebusch, 1997: 6-7).

Beyond foreign policy objectives, capabilities, and resources, scholars note that a fundamental element for the categorization of a state as a regional power is the acceptance of its status by those states with which it shares a regional system or subsystem, as well by those great powers that control or determine the rules of the game of the international system. Along that line, Nolte includes Iran in the "regional power" category, recognizing that in order to reach the status of a great power it is necessary to have not only the corresponding material resources but also the acceptance and formal recognition of this status by other great powers as well as an identifiable impact on the behavior of other regional states and great powers (Nolte, 2010: 886). Thus, a regional power is such because it can exercise its capacity to influence at the regional level, although it may also intend to project power on the international level. In this sense, Iran's foreign policy objectives generally align with its resources and capabilities, and on occasion, it intends to carry out political and diplomatic initiatives beyond the region.

Based on the abovementioned, the Iranian regional power aspiration had, depending on the regional and systemic context, supporters and detractors. US president Richard Nixon's foreign policy doctrine included the "twin pillars" policy that counted with both Iran and Saudi Arabia as the main regional allies in the Middle East to counter the expansion of Communism in the region (Hooglund, 1992: 322). Thus, under his presidency (1969-1974), and with Shah Mohammad Reza Pahlavi in power, Iran exerted its regional influence with the official acceptance of one of the great superpowers. President James Carter (1977-1981) continued with this recognition in his foreign policy doctrine when stressing that any attempt by external powers to seize the Persian Gulf and its oil would be considered against US interests. Consequently, Carter provided unconditional support to Iran until the Islamic Revolution of February 1979, and therefore the Shah Pahlavi had free hands to exert his influence on the region using mainly hard power tools, including indirect intervention and direct military action (Hunter, 2019). In the 1960s and 1970s, Iranian forces, actively participated in regional conflicts such as the Dhofar war in Oman - supporting Sultan Qaboos bin Said-, and the conflict between North and South Yemen in support of the northern royalists. Furthermore, Iranian officials intervened in the Indo-Pakistani conflict, and airplanes from the Royal Iranian Air Force participated in the Vietnam War in support of the US war effort. Iran also intervened in the Iraqi Kurdish rebellion, forcing the Baathist government to reach a border agreement on the Shatt al Arab strait that benefited Iran and left Iraq without a direct way to the Persian Gulf or a seaport (Halliday, 1979: 270-272). Saudi Arabia, the other pillar of the US' "twin pillar" policy, also supported all these actions and even participated in some of them jointly with Iran, such as in Yemen and Oman. Therefore, not only the US but also the Iranian neighbors recognized the Iranian aspiration of becoming an important regional actor. 
The situation drastically changed after the Islamic Revolution, and this acceptance of the Iranian regional role disappeared. The confrontation with the US, aggravated by the US Embassy hostage crisis ${ }^{3}$, ended with Carter's administration cutting diplomatic ties with Iran on April $7^{\text {th }}$, 1980; a situation that lasts until today. The same happened with Saudi Arabia and other regional actors that perceived the new Iranian revolutionary regime as a direct threat to their stability and survival. Shortly after the revolution, Iraq invaded Iran on September 22 $2^{\text {nd }}, 1980$ and thus set off an eight-year long war between the two countries. The Iran-Iraq war acted as a catalyst to consolidate the Islamic Republic and forced the Iranian revolutionary regime to aspire to a revolution that transcended its borders, to convert Iran into a model for other Muslim states, and to resist foreign interference in Iran's internal affairs. During Mir Hussein Mousavi's tenure as prime minister (1981-1989), the "export of the revolution" policy was implemented, with the creation of a worldwide Islamic front to fight against imperialism — and all its variants - based on the ideological-religious principles of the Islamic Republic (Ramazani, 1990b: 40-45). This new policy —which was combined with anti-American and anti-Soviet imperialism, anti-Zionism and the liberation of the oppressed peoples of the Third World-, directly confronted Saudi Arabia in the arena of religious legitimacy for two reasons. Firstly, because Saudi Arabia had the role of protector of the holy places of Mecca and Medina, which granted the kingdom the capacity to decide on the entry of pilgrims from all over the world. Secondly, due to the religious character of the founding Saudi-Wahhabi alliance that enabled the creation of the kingdom in 1932.

By definition, the anti-monarchism of the Iranian Republic, together with the abovementioned religious legitimacy challenge, extended the confrontation between Saudi Arabia and Iran beyond their bilateral relation, reaching all the regional scenarios where both states had the chance to influence both governments and peoples. Therefore, areas in the Middle East region with a majority Shi'a population, including Saudi provinces, became the focus of a longer struggle for regional influence and hegemony between both states (Chubin and Tripp, 1996: 10-15). Since 1979 until today, many regional developments intensified that struggle for religious legitimacy and regional hegemony between Iran and Saudi Arabia, such as the Palestine Peace Process (1990); the Gulf War (1991); the Afghanistan War (2001); the fall of Saddam Hussein (2003); the Arab Uprisings (2011); the emergency of ISIS (2014); the Syria civil war (2011); the Yemen war (2015); and the blockade against Qatar (2017), among others. In each one of these events, Iran tried to exert its influence over regional developments to maximize its gains, in order to achieve the long-term objective of

3. On November 5th 1979, a group of students stormed the US Embassy in Tehran and held most of its personnel hostage for 444 days until their release. The attackers belonged to the Followers of the Imam's Line, and presumably, the tacit approval of Imam Khomeini made it possible the storming against the provisional Prime Minister Mehdi Bazargan' will, who resigned as a result of the takeover. 
becoming a regional power, to the equal detriment of the US as well as other regional actors, mainly Saudi Arabia.

\section{IRANIAN FOREIGN POLICY PRIORITIES AND STRATEGIES}

Following those aspirations, Iran has implemented several foreign policy strategies aimed at achieving its overall foreign policy goal, both before and after the establishment of the Islamic Republic in 1979. Already in 1848, the then Prime Minister Mirza Taqi Khan, known as Amir Kabir, introduced the concept of "third power strategy" as a mechanism to remain equidistant from the Russian and British empires without falling into their control, when the Qajar dynasty started to show weakness facing the demands from the then great powers. A similar approach, labeled as "negative equilibrium", was popularized by Prime Minister Mohammad Mossadeq, when assuming power and nationalizing the Anglo-Iranian Oil Company in 1951; as well as implementing an equidistant policy towards both the United States and the Soviet Union. A reinforced Shah Pahlavi also instated both the "positive nationalism" and the "independent national policy" as foreign policy strategies to keep Iran independent from external powers as well as to convert Iran into a regional power (Ramazani, 1975).

Under Khomeini, "non-alignment" was implemented as the primary strategy that followed the same policy goal, but justified with a very different ideological framework and a combination of hard and soft power foreign policy tools, that derived from the different approaches that the various revolutionary groups had. With Khomeini exerting his ideological influence over the recently established political system, "neither East nor West, but the Islamic Republic" - in a clear reference to both the United States and the Soviet Union - and the "export of the revolution" became the most salient aspects of the Iranian foreign policy until he died in 1989 (Ramazani, 1990a: 74). In the 1990s, president Hashemi Rafsanjani (1989-1997) implemented "pragmatism" and "pragmatic regionalism" as the primary strategic mechanisms to reinsert Iran in the international order, which contributed to reaching out to the European Union, the GCC states and the post-Soviet Central Asian countries (Afrasiabi 1994: 31-33). This pragmatism contributed to Iran remaining neutral during the First Gulf War (1990-91) and Iran was therefore able to avoid sharing the same fate as the regime of Saddam Hussein.

The presidency of Mohammad Khatami (1997-2005) applied a soft power diplomatic approach towards the Muslim World as well as to the rest of the world through the "Dialogue among Civilizations" initiative. This strategy aimed at fortifying the Iranian position in the region by adhering to international law, and at the same time, reducing the Iranian confrontation with the United States based on common regional interests (Ehteshami, 2003: 125). Mahmoud Ahmadinejad, in the presidential office from 2005 to 2013, implemented a more confrontational policy towards the West, with a neoconservative ideological approach, to maximize territorial gains and fortify the resistance against "imperialism", especially concerning the nuclear program and 
Israel. Finally, Hassan Rouhani's administration (2013-2021) implemented an "accommodationist" approach that made a rapprochement with the United States and the signing the nuclear deal (JCPOA) possible, but without abandoning the non-alignment and regionalism from previous administrations or the long-term foreign policy goal of converting Iran into a "regional power" in the Persian Gulf and the Middle East (Zaccara, 2016: 194-196).

In each of these periods in which foreign policy goals, strategies, and tools were designed and implemented, a different combination of personalities, capacities, and resources was committed, settling the ADU able to shape the overall Iranian foreign policy. The following sections present the three specific cases in which Iran had to make crucial decisions and how the corresponding ADUs were shaped accordingly.

\section{IRAN AND THE ARAB UPRISINGS}

The so-called "Arab Spring" that started in Tunisia at the end of 2010 represented an ideological and strategic challenge for Iran. With the ashes of the Iranian "Green Movement" protests of 2009 still hot, the uprisings obliged Iranian authorities and politicians to pronounce themselves about the events, resulting in a new confrontational arena between the government and the opposition, as well as within the governmental structure.

While the lessons and failures of the Green Movement indirectly helped to organize the logistics of the demonstrations of the Arab Uprisings, (Kurzman, 2012: 164), a twofold debate also arose about whether the Green Movement served as an ideological and democratic inspiration for the revolts and whether the Islamic Republic provided a model for political organization. This debate generated different attitudes and actions by the government and the opposition regarding what has been called the "dual strategy of contestation and appropriation" (Mir-Hosseini, 2012). Reformist leader Mir-Hussein Mousavi unequivocally linked both anti-government movements — the Green Movement and the Arab Uprisings — "stating that the starting point of the events we are witnessing in the streets of Tunis, Sana'a, Cairo, Alexandria, and Suez must be sought in the massive demonstrations of June 14, 17 and 19 [2009] of Tehran. On those days, people took to the streets with the slogan of 'Where is my vote?' to peacefully demand their trampled rights" ${ }^{4}$. On the contrary, Khamenei declared that "today's events in North of Africa, Egypt, Tunisia, and certain other countries have another sense for the Iranian nation [...]. This is the same as 'Islamic Awakening', which is the result of the victory of the big revolution of the Iranian nation"s, asserting the unequivocal and perennial influence of the 1979 Islamic

4. Mousavi, Mir-Hussein. 2011. Mousavi Official Facebook page. Available at: http://facebook. com/Mousavi.

5. Khamenei, Ali. 2011. Leader Official Webpage. Available at: https://cutt.ly/4mE0AmC. 
Revolution on the Arab revolts. Paradoxically, both rationales coincided in their support for the movements in Tunisia and Egypt, with the opposition calling for demonstrations on February $14^{\text {th }}, 2011$. However, this ended with the reform leaders Mousavi and Mehdi Karroubi being placed under house arrest since February $24^{\text {th }}$-although no formal charges have been filed against them- until today ${ }^{6}$. Nonetheless, the government harshly criticized the regimes of Hosni Mubarak in Egypt, Ali Abdullah Saleh in Yemen, Moamar Gaddafi in Libya, and Hamad bin Khalifa in Bahrain, vindicating Arab peoples' right to choose their rulers and overthrow dictatorships, whether republican or monarchical. However, this narrative was not repeated with Syria, whose government was explicitly supported, except for 2012, when the Ahmadinejad government began to distance itself a bit, recommending the Assad government to be more flexible and negotiate with the opposition. Iranian support was justified based on the country's anti-Israeli and anti-American foreign policy, not shared by the other states where anti-government uprisings occurred (Zibakalam, 2011).

The difference of narratives was also visible between the leadership and the presidency. While Khamenei considered the "Middle East developments [...] derived from the Islamic Revolution of Iran and [...] largely of a religious and Islamic nature, though they have been manifested through economic and social demands", Ahmadinejad stated that the "upheavals are a result of a United States-Israeli conspiracy aiming at dividing and undermining the Muslim world" (Haji Yousefi, 2012: 24). While for the leader, the revolts were an "Islamic Awakening", Ahmadinejad initially used "American Awakening" or "Human Awakening" to define the events that he considered were linked to the United States' agenda of interference in the Middle East.

Later on, Ahmadinejad repeated three times "long live this Spring" during his speech at the United Nations General Assembly in September 20127 , and on the 34th anniversary of the Islamic Revolution, he expressed "viva Spring" (Jedinia, 2013) from the podium. Moreover, Ahmadinejad stated that "the only solution to the crisis in Syria is building a national consensus and holding free elections" ${ }^{8}$, a position that the Leader did not share, nor Ahmadinejad's successor to the presidency, Hassan Rouhani.

The coexistence of different political views within the Iranian establishment and the foreign policy complex prevented a clear and unified response to the challenges posed by the Arab Uprisings in scenarios such as Libya, Bahrain, and Syria. Iran was surprised by the "unexpected unity of the GCC and its unusual decisiveness in response to developments in Bahrain. Clearly, under Saudi leadership, the GCC had decided to 'draw the line' in Bahrain" (Chubin, 2012: 22). With Hassan Rouhani as

6. BBC. 2011. "Iran: Mir Hossein Mousavi and Mehdi Karroubi 'arrested" BBC, 28-2-2011. Available at: http://www.bbc.co.uk/news/world-middle-east-12599837.

7. Dehghan, S. 2013. "Ahmadinejad's new pet phrase 'spring' infuriates Iranian establishment", The Guardian, 13-3-2013. Available at: https://cutt.ly/ZmE63uy.

8. Ahmadinejad, Mahmoud. 2012. Iran President Official Webpage. Available at: http://president. ir/en/42678/preview?term=Syria. 
president, that discrepancy disappeared, since he sided with the official leadership position. It became more evident with the emergence of Daesh in both Iraq and Syria when Iran started to commit many more resources to support its allies in both countries to prevent their fall. Defeating Daesh became imperative since both Syria and Iraq were considered an integral part of Iran's strategic defense. Failing to defeat Daesh on Syrian or Iraqi soil could have led to a direct confrontation along the Iranian borders, or even within the country. The actual threat that this represented was shown by several terrorist attacks that Iran suffered on its soil in 2017 and 2018. By this time, however, it had become evident that President Rouhani's control over Iranian foreign policy towards these two scenarios in Syria and Iraq was minimal, and instead, were under the direct control of the IRGC, mainly General Qasem Soleimani.

During the initial period of the "Arab Uprisings" there were different —and confronted - approaches and interpretations of the revolts, but any of the components of the foreign policy complex had by itself the capacity to mobilize all the necessary resources. The Iranian reaction to the "Arab Uprisings" therefore demonstrates that the ADU that shaped the foreign policy decisions along this initial period varied due to the diversity of approaches within the several institutions that formed part of the decision-making process, and the personal capacities of those occupying those positions. While Ahmadinejad was in office, the ADU type was a "Coalition of Autonomous Actors", whereas once Rouhani assumed power and the IRGC got directly involved in the implementation of the Iranian foreign policy, then the "Single Group" ADU type was in place. The line of action was also in line with the overall Iranian aspiration of becoming a regional power by supporting revolts that would reshape the regional order to the benefit of Iran and to the detriment of its adversaries, mainly the US and Saudi Arabia.

\section{IRAN AND THE NUCLEAR NEGOTIATIONS}

Before Hassan Rouhani's victory in the presidential elections in June 2013, secret backchannel talks took place between high-level Iranian and American officials in Muscat. There were five more meetings after the June elections, which led to the renewed negotiation efforts that ended with the signing of the "Joint Comprehensive Plan of Action" (JCPOA) in 2015. While it is clear that the secret talks started during Ahmadinejad's term, it is not that clear whether it was him or Khamenei who authorized this direct interaction with the United States?.

The first official landmark took place on September 27th 2013, with a phone conversation between president Rouhani and his counterpart president Obama, at the

9. Hashemi Rafsanjani mentions during a speech that the Supreme Leader was the primary architect of the new approach towards the nuclear issue before Rouhani's election as he wanted to resolve the issue diplomatically. Available at: https://www.youtube.com/watch?v=SwwutJkMyI. 
end of the United Nations General Assembly. The official statements regarding that phone conversation were carefully negotiated to avoid backlash in both the U.S and Iran ${ }^{10}$. The result of this big step was the signing of the November 2013 provisional deal in Geneva, followed by the implementation of the six-month deal starting on January $20^{\text {th }} 2014$, and the release of some 500 million dollars in frozen assets in February 2014. Previously, the inspections of the IAEA certified that Iran had complied with the suspension required in the Geneva deal. Iran was guaranteed its right to develop a full cycle of nuclear energy and the promise of sanctions lifted, in exchange for suspending its uranium enrichment activities, reducing the number of centrifuges, impoverishing the already enriched uranium and reducing its stockpile as well as accomplishing complete transparency and supervision of the whole program for a 25 year period time.

It is worth mentioning that for the first time since the Islamic Revolution, an American administration recognized a political-religious statement issued by the Leader as binding for the foreign policy behavior in such a way that it guarantees Iran's fulfillment of the signed deal. On April $2^{\text {nd }}$, Obama stated that: "This deal offers the prospect of relief from sanctions that were imposed because of Iran's violation of international law. Since Iran's Supreme Leader has issued a fatwa against the development of nuclear weapons, this framework gives Iran the opportunity to verify that its program is, in fact, peaceful" 11 .

The fatwa, issued by Khamenei in August 2005, considered it un-Islamic and forbidden to produce, use and stockpile nuclear weapons ${ }^{12}$.

The provisional deal was renewed for another six months while the negotiations continued during 2014 in Geneva. Finally, on April 2 ${ }^{\text {nd }}, 2015$, the European Union Foreign Policy Representative - Federica Mogherini- and Iranian Foreign Minister - Mohammad Javad Zarif - announced the JCPOA in a joint declaration. The JCPOA was endorsed on July $14^{\text {th }}, 2015$ in a long-waited official ceremony attended by all representatives from Iran, the EU, the United States, Russia, the United Kingdom, France, China, and Germany. The 159-pages document, including the core text and five technical annexes, set the limitation of nuclear activities in a range of 15 to 25 years, as well as a "snap back" mechanism that would allow the UN/SC to quickly reinstate the sanctions in case Iran would not fulfill its obligations towards the deal. The JCPOA established the calendar of implementation and sanctions release

10. See: The White House Office of the Press Secretary. Statement by the President, September 27th, 2013 (available at: https://cutt.ly/smRqpoZ) and منن كامل سخنان رييس جمهور در جمع خبرنحار ان. October $3^{\text {rd }}, 2017$ (available at: https://cutt.ly/6mRqfLl).

11. Obama, Barack. 2015. "Statement by the President on the Framework to Prevent Iran from Obtaining a Nuclear Weapon”, The White House President Barack Obama, 2-4-2015. Available at: https://cutt.ly/ymE9kaJ.

12. Excerpts from the original oral fatwa are cited literally at the official Khamenei's website, at the fatwa section in Farsi, English and Spanish languages. Available at: https://farsi.khamenei.ir/ treatise-content?id=228\#2790. 
upon the IAEA inspector's confirmation of the Iranian fulfillment of all conditions imposed by the deal. Both the US Congress and the Iranian Majlis ratified the JCPOA as prescribed in the deal.

The JCPOA represented a serious Iranian commitment vis à vis the international community, with the renouncement of previous achievements, the freezing of the nuclear program for 25 years, and a robust transparency and safety conditionality. In exchange, Iran achieved for the first time international recognition of its right to develop a nuclear program under the Non-Proliferation Treaty and AIEA supervision. Iran also was promised the lifting of sanctions, and more importantly, the promise of no more new sanctions imposed on the nuclear program.

Both, the US and Iran, were aware that the nuclear deal was a necessary step to reduce tensions in the region, even though none of the parties (or signatories) was one hundred percent satisfied with the terms of the deal. Obama recognized that this was "a deal between states that are not friends", a "deal based in verification and not in trust" 13 , whereas Zarif recognized that "it was not a perfect deal" ${ }^{14}$. Both sides had to make concessions to reach an agreement.

A combination of factors facilitated a collective decision made within the Iranian political structure that ended with the JCPOA and the Iranian commitment with the international community as well as direct negotiations with the US. A "Single group" ADU style was in place, since different groups and actors, within the Majlis, the presidency, the leadership, and other collective institutions, shared the same need to sign the JCPOA. Even though the deal was harshly criticized by the system's hardliners, the foreign policy complex supported the line of action marked by Rouhani and Zarif. The deal was authorized by the leader and supported by the National Security Council — chaired by Ali Shamkhani-, the Expediency Council — led by Hashemi Rafsanjani- and the Parliament — chaired by Ali Larijani and controlled by the moderates and reformists since the February 2016 legislative elections. Although from a different political faction than Rouhani, Larijani, as chair of the Majlis, played a crucial role in guaranteeing the parliamentary approval of the $\mathrm{JCPOA}^{15}$. Nonetheless, the ADU changed its composition after the demise of Hashemi Rafsanjani in January 2017. This event unbalanced the situation in favor of the conservatives, with Sadegh Larijani chairing the Expediency Council, and some legislative decisions indirectly related to the JCPOA paralyzed by the council ${ }^{16}$.

13. BBC. 2015. "Obama: 'Iran nuclear deal not based on trust”, $B B C$, April 4-4-2015. Available at: https://cutt.ly/MmRqSvl.

14. Jay, M. 2015. “The hidden agendas of Iran deal. Daily Sabah”, 23-7-015. Available at: https:// cutt.ly/QmRqJ4t.

15. Tasnim News Agency. 2018. "توضيح لاريجانى درباره "تصويب • r دقيقهاى برجام در مجلس. Available at: https://cutt.ly/imRqCWJ.

16. The Financial Action Task Force (FATF) requested Iran to pass legislation to prevent money laundering and the financing terrorism. While Parliament passed the legislation in October 2018, it was delayed and finally rejected by the Expediency Council in February 2020. 
The signing of the JCPOA was also consistent with the Iranian long-term foreign policy objective. As abovementioned, the official US recognition of Iran's right to a nuclear program under the supervision of the IAEA represented a clear acceptation of the Iranian role in the regional context (Zaccara and Haghirian, 2020: 73). While the recognition of the Iranian right of having a nuclear program was explicit through the signature of the JCPOA and Obama's words, the recognition of Iran regional power was implicit, due to the weight of belonging to the list of countries with nuclear capacity has in terms of actual power. This last was evident with the negative reception the deal had in some GCC states and Israel, since it was conceived as disrupting the regional equilibrium on the benefit of Iran, with enough available resources to extent its influence in the broader Middle East region ${ }^{17}$. Therefore, the line of action taken by Iran on the nuclear negotiation was successful in achieving that goal of becoming a regional power, despite the rejection from regional actors.

The Iranian decision was also consistent with the pre-existing alliance with Russia. The sanctions implemented since 2006 by the United Nations Security Council on the nuclear program exempted the construction of the Bushehr nuclear power reactor by the Russian Rosatom. The contract had been signed in 1995, and it was completed by 2016, when the Iranian Nuclear Power Production and Development Company (NPPD) received the operating license for the reactor from the Russian national nuclear regulator. Although Russia conditioned its support of the sanctions to the exemption, it delayed the delivery of feasible material to the nuclear plant until the JCPOA was signed. In the Chinese case, nuclear cooperation with Iran stopped in 1997 due to the pressure from Washington, that forced Beijing and other capitals to cancel their preexisting agreements with Iran to avoid being penalized by the US IranLibya Sanction Act implemented by the Clinton administration in 1996. In that regard, the signature of the JCPOA opened the door for a closer collaboration with Russia in expanding the Bushehr project. It also unlocked the nuclear collaboration with China paralyzed since 1997. With the visit of the Chinese President Xi Jinping to Tehran in January 2016 and the signature of the Comprehensive Strategic Partnership that included the Iranian incorporation of the Chinese Belt and Road Initiative, and moreover, since the signature of the 25-year Strategic Plan the prospect for nuclear cooperation became more feasible than ever before.

Chinese and Russian support for the JCPOA was therefore justified by their strategic but also commercial interest in providing Iran with the needed nuclear technology to develop the outdated energy infrastructure. In this regard, Iranian decision

17. Al Jazeera. 2015. "Why Saudi Arabia and Israel oppose Iran nuclear deal", 14-1-2015 (available at: https://cutt.ly/5mRq9vq); BBC. 2015. "Israel's Netanyahu warns US against 'paving way to Iran bomb", 3-3-2015 (available at: http://www.bbc.com/news/world-middleeast-31716684); Riedel, Bruce. 2016. "What the Iran deal has meant for Saudi Arabia and regional tensions", Brookings, 13-7-2015 (available at: https://cutt.ly/amRwsjL); Plett Usher, B. 2015. "Iran deal could start nuclear fuel race. Saudi Arabia", BBC, 16-3-2015 (available at: http://www.bbc.com/news/world-middle-east-31901961). 
to engage in the nuclear deal was also in line with the general foreign policy objectives and the privileged position that Tehran had in Moscow and Beijing.

\section{IRAN AND THE GCC CRISIS}

On June $5^{\text {th }}, 2017$, an air, land, and sea blockade was imposed on Qatar by the Arab quartet including Saudi Arabia, Bahrain, the United Arab Emirates and Egypt, which marked the onset of a Gulf Cooperation Council (GCC) crisis. The rift erupted soon after the reelection of Hassan Rouhani in Iran on May 19th, and only a few days after the "Arab Islamic American Summit" had been held in Riyadh on May $21^{\text {st }}$. During his two-day visit to the Kingdom, President Donald Trump sought to strengthen ties between the United States and Saudi Arabia and also to increase the pressure on Iran. In this context, Trump introduced the Middle East Strategic Alliance (MESA or "Arab NATO") as a military defense agreement against the perceived Iranian threat (Farouk, 2019). Trump accused Iran of fueling sectarian conflicts and terrorism in the region by providing a "safe harbor, financial backing, and the social standing needed for recruitment" by the terrorists ${ }^{18}$. While Iran engaged in denouncing Trump's speech at the Summit, an unprecedented crisis spiraled between Qatar and the Saudi led quartet because of a hacking of the state-run Qatar News Agency. The hacked news quoted the Qatari Emir Sheikh Tamim Al Thani as calling Iran an "Islamic power" and criticized the Gulf States' heightened tensions with Iran. Not surprisingly, the first of the thirteen demands issued on 23 June by the blockading quartet to end the crisis demanded Qatar to cut diplomatic ties with Iran: "Scale down diplomatic ties with Iran and close the Iranian diplomatic missions in Qatar, expel members of Iran's Revolutionary Guard and cut off military and intelligence cooperation with Iran. Trade and commerce with Iran must comply with US and international sanctions in a manner that does not jeopardize the security of the Gulf Cooperation Council”"19.

Thus, Iran was instrumentalized as scapegoat to orchestrate a diplomatic rift with Qatar by the blockading Arab states.

Qatar-Iran relations were not at their best at the onset of the Arab Uprisings since the two engaged with opposing factions in regional conflicts across the region. While Qatar maintained that Hezbollah, backed by $\operatorname{Iran}^{20}$, was a terrorist organization, Iran shared the Saudi accusation regarding Qatar's sponsorship of extremist groups in

18. Trump, Donald. 2017. "President Trump's Speech to the Arab Islamic American Summit", The White House, 21-5-2017. Available at: https://cutt.ly/BmE9Twk.

19. Al Jazeera. 2017. "Arab states issue 13 demands to end Qatar-Gulf Crisis", 12-7-2017. Available at: https://cutt.ly/BmRwRl0.

20. Naylor, H. 2016. "In jab at Iran, Gulf Arab states declare Hezbollah, a terrorist group”, Washington Post, 2-3-2016. Available at: https://cutt.ly/7mRwAjE. 
Syria that were fighting against the Iranian backed Assad regime. This includes for instance, the Al Nusra Front, which was somehow recognized by Qatar — although presumably stopped doing that ${ }^{21}$. Qatar has often been perceived by Tehran as a country hostile to, or at least not friendly to, Iranian interests, even though Iran tolerated Qatar's deference towards Saudi Arabia — for instance in participating officially in the Saudi led coalition in the war in Yemen or reducing diplomatic relations in 2016 after the Saudi embassy storming in Tehran. Howbeit, the Iranian government immediately sided with Qatar in the crisis. The GCC crisis's outbreak gave Iran the opportunity to prioritize its confrontation with Saudi Arabia by supporting Qatar.

In this context, there were several direct communications between Iranian and Qatari officials, which not only made the Iranian support explicit but also accelerated bilateral relations. On August 23 ${ }^{\text {rd }}$, Qatar announced that its Ambassador to Iran would be sent back to Tehran with the "aspiration to strengthen bilateral relations with the Islamic Republic of Iran in all fields"22. This took place soon after a phone call between the two Foreign Ministers, Sheikh Mohammed bin Abdulrahman Al-Thani and Mohammed Javad Zarif. During the conversation, they discussed "bilateral relations and means of boosting and developing them as well as a number of issues of common concern". At the end of August, Rouhani had a phone call with Sheikh Al-Thani, and expressed Iran's willingness to strengthen the bond among Muslim countries of the region and expressed that "the Islamic Republic of Iran believes that what is being imposed on Qatar is unjust and it leads to more tension among countries of the region" 23 . The Iranian government's support for Qatar went beyond its declaration at the political level. Since the beginning of the crisis, Iran showed staunch support and expressed its willingness to prevent the blockade from affecting Qatar, its economy, and its population. Tehran swiftly set up new time slots to expedite the use of the Iranian airspace for Qatar Airways flights, which due to the air ban, needed to use alternative air routes ${ }^{24}$. Moreover, Iran sent planes carrying tons of food to Qatar to overcome the problems posed by the quartet's boycott and blockade.

There was also a surge in trade between Qatar and Iran as Iranian businesses began to tap into growing opportunities in Qatar, which sought for non-oil trading partners to replace the trade links broken with Saudi Arabia and Emirates. Besides, Iranian producers and business delegations visited Doha since June 2017 intending to establish permanent links with the Qatari market. In November 2017, bilateral ministerial,

21. Middle East Eye. 2017. "Qatar 'maybe' supported al-Qaeda in Syria, says former PM”. Middle East Eye, 30-10-2017. Available at: https://cutt.ly/RmRwFT4.

22. MOFA. 2017. "Qatar Announces Return of its Ambassador to Tehran”, Qatar Ministry of Foreign Affairs, 23-8-2017. Available at: https://cutt.ly/WmE2IrW.

23. MFA. 2017. "President Rouhani held a phone conversation with Qatar Emir Al Thani". Available at: https://cutt.ly/AmE04sQ.

24. According to a technician at Hamad International Airport, the standard time allocated between aircrafts to cross the Iranian airspace was three minutes, which the Iranian authorities reduced to 2 minutes to accommodate Qatar's needs. 
as well as chamber of commerce meetings were held ${ }^{25}$. Data from the Iran Customs Administration show that Iran exported 139 million dollars' worth of non-oil goods to Qatar during seven months until October $22^{\text {nd }}, 2017$ - a timeframe covering both pre- and post-boycott periods. That was a $117.5 \%$ increase compared to the same period a year earlier ${ }^{26}$.

According to a survey conducted by the Social and Economic Survey Research Institute at Qatar University, the Qatari perceptions of Iran had drastically improved due to the helping hand lent to Qatar by Iran during the initial days of the blockade and even later as it continued (SESRI, 2018).

The Qatar-Gulf crisis 2017 provided Iran a chance to convey to Qatar and to the rest of the Gulf and Arab that Saudi Arabia was the real threat to their independence and sovereignty, while Iran was there to help when a neighboring state was in need to overcome an unfair and illegal blockade. Threat perceptions shifted towards Saudi as a regional hegemon seeking dominance over smaller Gulf States within the GCC. Despite the Iranian concerns regarding Qatari support for groups opposed to Iranian interests in regional scenarios, Iran sided with Qatar, using a pragmatic approach that prioritized the long-term confrontation with Saudi Arabia. Iran showed readiness to help in any possible way and swiftly expressed its strong support to the Qatari Emir and mobilized all productive forces to guarantee the provision of fresh goods in the first weeks of the blockade. The crisis also helped Iran to move away from conventional sectarian narratives by strengthening its relations with Doha and Ankara despite their rivalries in the Syrian crisis and other regional issues, as well as the more longterm differences at the ideological and religious level.

Nonetheless, Qatar is hosting the Al Udeid base, the regional headquarters for the US Central Command that allocates almost seven thousand soldiers, and puts both states in a susceptible situation amid the increased tension between Tehran and Washington. Also sensitive is the fact that the re-imposed US sanctions on Iran are definitively having an impact on Qatar-Iran relations, although not to such extent as to force Qatar to break its ties with Iran. It is undeniable that US-Qatar relations are essential for the survival of the Emirate at the military level. It is also true that the GCC states continued to arm themselves heavily, spending on military and defense equipment in response to the perceived threat of Iranian military strength (Jarzabek, 2016). In addition, it is evident that the Qatari government would not risk losing it because of their lack of compliance with the US restrictions.

The generalized perception within the Iranian establishment was of pragmatic decision-making aimed at maximizing the gains of an internal rift among GCC member states. The leadership, the presidency, the commercial sector as well as the

25. IFP News. 2017. "Iran FM, Qatari Minister Call for Promotion of Business Ties", Iran Front Page News, 26-11-2017. Available at: https://cutt.ly/pmReqAg.

26. Dudley, Dominic. 2017. "How Qatar Is Being Pushed into The Arms of Iran By Saudi Arabia And Its Allies. Forbes, 27-11-2017. Available at: https://cutt.ly/VmRetzd. 
military apparatus, supported Iran's approach to the GCC crisis, siding with the most profitable partner within the Persian Gulf context apart from Iraq. While Khamenei's involvement in the decision was not evident, and all the diplomatic contacts were held by Rouhani's administration, his tacit support for the Iranian approach was visible in the tone of his official declarations, speeches, and meetings. The decision was also consistent with the long-term foreign policy goal. By intervening in the intra-GCC spat, Iran demonstrated its capacity to exert influence in the regional context, balancing the existent alliances in the region, and performing its role in a way that could have been praised by other regional and external actors as stabilizing rather than destabilizing. In this last case, the "Single group" ADU type was in charge of the policy action taken. The President and Foreign Ministry as well as the Leader and the chairmen of the Majlis and other councils shared a similar approach of prioritizing the bilateral relations with $\mathrm{Qatar}^{27}$.

\section{CONCLUSIONS}

Following the theoretical framework of the Foreign Policy Analysis and the Authoritative Decision Units approach established by Hermann, this article aimed at explaining the Iranian decision-making process. First, it detailed how the Iranian foreign policy complex works, with a combination of several individuals and collective actors involved in the design and implementation of the foreign policy. Second, it described the recurrent primary foreign policy goal before and after the Islamic Revolution, converting Iran into a regional power. Third, it established the Iranian foreign policy strategies implemented throughout the 20th and 21 st centuries, which focused on maintaining a non-aligned and independent position within the international system, with the final aim of achieving that primary goal. Finally, the article focused on three recent events that posed a challenge for the Iranian foreign policy complex: the2011 Arab Uprisings, the nuclear negotiations 2013-15, and the GCC crisis that provoked blockade against Qatar in 2017.

The analysis of the three Iranian responses has shown that there was not a single actor deciding any of them, but instead, a combination of actors or groups of actors. Those eventually agreed on the foreign policy objectives, but also disagreed on some other issues. While pragmatism seemed to be behind the rationale that materialized in such decisions, this pragmatism seems to be the result of collective negotiations, rather than a single actor's unilateral decision. The arbitrariness of the Iranian foreign policy

27. Al Jazeera. 2017. “Iran: Hassan Rouhani condemns 'siege of Qatar”, 25-6-2017 (available at: https://cutt.ly/2mRefCd); Middle East Eye. 2017. "Iranian foreign minister calls out Qatar blockade”, 27-6-2017 (available at: https://cutt.ly/vmRelh6); Financial Tribune. 2018. "Larijani Urges Negotiated Solution to Regional Conflicts", 9-7-2018 (available at: https://cutt. ly/1mRevzq). 
attributed by some analysis is not sustained by the evidence, which proved otherwise. Iran reacted towards the Arab Uprisings as a reflection of the diversity of ideological and political approaches existing within the establishment. Only when the authoritative decision units coincided with the same approach, it was reflected in a more coherent foreign policy. The same happened with the signing of the JCPOA after the nuclear negotiations, since the different groups that were able to mobilize resources shared the same necessity to end the nuclear controversy. Similar considerations served the Iranian position on the blockade against Qatar. In none of the three cases was the decision taken by a single actor, but rather, by a combination of actors that shaped the authoritative decision units within the Iranian foreign policy complex.

Furthermore, the decisions made in the three cases were consistent with the longterm Iranian foreign policy objective of becoming a regional power in the Persian Gulf and the Middle East. The foreign policy actions taken fell within the strategies designed by the foreign policy complex, and each of them aimed at maximizing Iran's benefits in the regional context to achieve that regional power goal.

\section{References}

Afrasiabi, Kaveh. 1994. After Khomeini. New Directions in Iran's Foreign Policy. Boulder; San Francisco; Oxford: Westview Press.

Checkel, Jeffrey. 2008. "Constructivism and foreign policy", in Steve Smith, Amelia Hadfield and Tim Dunne (eds.), Foreign Policy. Theories, Actors, Cases. Oxford: Oxford University Press.

Chubin, Shahram. 2012. Iran and the Arab Spring: Ascendancy Frustrated. GRC Paper. Gulf Research Center. Available at: https://carnegieendowment.org/files/Iran_ and_Arab_Spring_2873.pdf.

Chubin, Shahram and Charles Tripp. 1996. Iran Saudi Arabia Relations and Regional Order. London: Oxford University Press.

Ehteshami, Anoush. 2003. "Iran-Iraq Relations Alter Saddam", The Washington Quarterly, 26 (4): 115-129. Available at: https://doi.org/10.1162/016366003322387145.

Ehteshami, Anoush and Raymond Hinnebusch. 1997. Syria and Iran: middle powers in a penetrated regional system. London; New York: Routledge.

Entessar, Nader and Kaveh Afrasiabi. 2017. Iran Nuclear Accord and the Remaking of the Middle East. Lanham: Rowman and Littlefield Publishers.

Farouk, Yasmine. 2019. "The Middle East Strategic Alliance Has a Long Way to Go", Carnegie Endowment for International Peace, 8-2-2019. Available at: https://cutt. ly/YmE1M03.

Haji-Yousefi, Amir. 2012. "Iran and the 2011 Arab Revolutions: Perceptions and Actions", Discourse: An Iranian Quarterly, 10 (1-2): 23-60.

Halperin, Morton and Priscilla Clapp. 2006. Bureaucratic Politics and Foreign Policy. Washington: Brookings Institution.

Halliday, Fred. 1979. Iran, dictatorship and development. New York: Penguin Books. 
Halliday, Fred. 2005. The Middle East in International Relations. Cambridge: Cambridge University Press.

Hermann, Margaret. 2001. "How Decision Units Shape Foreign Policy”, International Studies Review, 3 (2): 47-81. Available at: https://doi.org/10.1111/1521-9488.00234.

Hinnebusch, Raymond. 2002. "Introduction: The Analytical Framework", in Raymond Hinnebusch and Anoushiravan Ehteshami (ed.), The Foreign Policies of Middle East States. London: Lynne Rienner.

Holsti, Kal. 1970. "National Role Conceptions in the Study of Foreign Policy", International Studies Quarterly, 14 (3): 233-309. Available at: https://doi.org/10.2307/ 3013584.

Hooglund, Eric. 1992. "The Persian Gulf”, in Peter J. Schraeder (ed.), Intervention into the 1990s. U.S. Foreign Policy in the Third World. Boulder: Lynne Rienner.

Hudson, Valerie. 2008. "The history and evolution of foreign policy analysis", in Steve Smith, Amelia Hadfield and Tim Dunne (eds.), Foreign Policy. Theories, Actors, Cases. Oxford: Oxford University Press.

Hunter, Shireen. 2019. "The Persian Gulf Crisis: Beyond the Carter Doctrine", Lobe Log, 23-9-2019. Available at: https://cutt.ly/LmE0hlp.

Jarzabek, Jaroslaw. 2016. "GCC. Military Spending in the Era of Low Oil Prices”, Middle East Institute, 8-8-2016. Available at: https://cutt.ly/VmE0vfZ.

Jedinia, Mohammad. 2013. "Ahmadinejad Declares 'Viva Spring' in Iran”, $A l$ Monitor, 13-2-2013. Available at: https://cutt.ly/rmE0YaD.

Kurzman, Charles. 2012. "The Arab Spring: Ideals of the Iranian Green Movement, Methods of the Iranian Revolution", International Journal of Middle East Studies, 44, 162-165. Available at: https://doi.org/10.1017/S0020743811001346.

Mir-Hosseini, Ziba. 2012. "Iranian responses to the 'Arab spring': appropriation and contestation”, Open Democracy, 9-2-2012. Available at: https://cutt.ly/bmE2ge7.

Nolte, Detlef. 2010. "How to compare regional powers: analytical concepts and research topics", Review of International Studies, 36 (4): 881-901. Available at: https://doi.org/10.1017/S026021051000135X.

Nonneman, Gerd. 2005. "Analyzing the Foreign Policies of Middle East and North Africa: A Conceptual Framework", in G. Nonneman (ed.), Analyzing Middle East Foreign Policies and the Relationship with Europe. London: Routledge. Available: https://doi.org/10.4324/9780203008829.

Ramazani, Ruhollah. 1975. Iran's Foreign Policy, 1941-1973. A Study of Foreign Policy in Modernizing Nations. Charlottesville: University of Virginia Press.

Ramazani, Ruhollah. 1990a. "Iran's export of the revolution: politics, ends and means", in John L. Esposito (ed.), The Iranian Revolution. Its Global Impact. Miami: Florida International University Press.

Ramazani, Ruhollah. 1990b. "Iran's Resistance to the U.S. Intervention in the Persian Gulf”, in Nikki R. Keddie and Mark J. Gasiorowski (eds.), Neither East nor West. Iran, the Soviet Union and the United States. New Haven: Yale University Press.

Ramazani, Ruhollah. 2013. Independence without Freedom: Iran's Foreign Policy. Charlottesville: University of Virginia Press. 
SESRI. 2018. Qatar against the Blockade. SESRI Omnibus Survey, 1-8-2018. Available at: https://cutt.ly/TmE9mlJ.

Zaccara, Luciano. 2016. "Iran's permanent quest for regional power status", in Jacqueline Anne Braveboy-Wagner (ed.), Diplomatic Strategies of Leading Nations in the Global South: Asia, Africa, Latin America, and the Middle East. New York: Palgrave Macmillan. Available at: https://doi.org/10.1057/978-1-137-45226-9_7.

Zaccara, Luciano and Mehran Haghirian. 2020. "Rouhani, the Nuclear Deal, and New Horizons for Iran-US Relations", in Luciano Zaccara (ed.), The Foreign Policy of Iran under President Hassan Roubani First Term (2013-2017). Singapore: Palgrave Macmillan. Available at: https://doi.org/10.1007/978-981-15-39244 4.

Zibakalam, S. 2011. "Syria spoils the Iranian victory", Bitterlemons International, 31 (9): 27.

Presented for evaluation: October $20^{\text {th }}, 2020$.

Accepted for publication: May 21 2021.

\section{LUCIANO ZACCARA}

luciano.zaccara@qu.edu.qa

ORCID: 0000-0002-7429-0886

Research Assistant Professor in Gulf Politics at the Qatar University, Gulf Studies Center; Visiting Assistant Professor at the Georgetown University in Qatar, and Director of the Observatory on Politics and Elections in the Arab and Muslim World, Spain. PhD in Arab and Islamic Studies from Autonomous University of Madrid, Spain and BA in Political Science from National University of Rosario, Argentina. Post-doctoral fellow at Autonomous University of Barcelona; Visiting Researcher at Exeter University, Institute for Arab and Islamic Studies; and Visiting Researcher at Princeton University, Center for Iran and Persian Gulf Studies. His research interests are Iranian Politics and Foreign Policy; Gulf Politics; International Relations in the Persian Gulf; and Electoral Systems in MENA region. His latest publication is "Foreign Policy of Iran under President Hassan Rouhani's First Term (2013-2017)", Zaccara, Luciano (ed.), Palgrave Macmillan, 2020. 